\title{
Role of metabolic and cellular proliferation genes in ruminal development in response to enhanced plane of nutrition in neonatal Holstein calves ${ }^{1}$
}

\author{
A. Naeem, ${ }^{*}$ J. K. Drackley, ${ }^{*} \dagger$ J. Stamey, ${ }^{*}$ and J. J. Loor ${ }^{*} \dagger^{2}$ \\ *Department of Animal Sciences, and \\ †Division of Nutritional Sciences, University of Illinois, Urbana 61801
}

\begin{abstract}
We evaluated expression of 50 genes encoding enzymes involved in metabolism, cellular growth, and various transporters in ruminal epithelium tissue when calves were fed conventional milk replacer (MR) and starter (control) or enhanced MR and enhanced starter. Male Holstein calves were fed reconstituted control MR [20\% crude protein (CP), $20 \%$ fat; $0.57 \mathrm{~kg}$ of solids/ calf] plus conventional starter $(19.6 \% \mathrm{CP}$, dry matter basis) or a high-protein MR (ENH; $28.5 \%$ CP, $15 \%$ fat; at $\sim 2 \%$ of body weight) plus high-CP starter $(25.5 \%$ $\mathrm{CP}$, dry matter basis). Groups of calves in control and ENH were harvested after $43 \mathrm{~d}$ (wk 5) and $71 \mathrm{~d}$ (wk 10) of feeding. Ruminal epithelium from 5 calves ( 3 to 42 d age) in each group was used for transcript profiling using quantitative reverse transcription PCR. No differences were observed for plasma $\beta$-hydroxybutyrate (BHBA) concentration but BHBA increased by wk 10 regardless of treatment. Reticulorumen mass postweaning was greater in calves consuming the ENH diet and corresponded with overall greater serum insulin. A marked upregulation of the ketogenic genes HMGCS2, $H M G C L$, and $B D H 1$ was observed, concomitant with downregulation of expression of genes involved in fatty acid oxidation $(C P T 1 A, A C A D V L)$ at wk 10. Higher relative percentage mRNA abundance of HMGCS2 ( $\sim 40 \%$ of total genes assayed), the rate-controlling enzyme in hepatic ketogenesis, underscored its importance for ruminal cell energy metabolism. Higher PPARA expression and blood nonesterified fatty acids at wk 5 due to ENH were suggestive of more extensive longchain fatty acid oxidation in ruminal epithelial cells during the milk-fed phase. In contrast, calves fed control consumed more starter during the milk-fed phase, which likely increased production of volatile fatty acids and accounted for higher expression of propionyl-CoA carboxylase $(P C C A)$ and the $\mathrm{Na}^{+} / \mathrm{H}^{+}$exchanger 2
\end{abstract}

Received July 8, 2011.

Accepted November 23, 2011.

${ }^{1}$ Supported by Hatch funds under project ILLU-538-326 (National Institute of Food and Agriculture).

${ }^{2}$ Corresponding author: jloor@illinois.edu
(SLC9A2) at wk 5. Expression of G-coupled protein receptors for short-chain fatty acids was undetectable. The expression of the urea transporter (SLC14A1) increased markedly with age and was correlated with the increase in blood urea N. Expression of genes involved in cell proliferation (INSR, FOXO1, AKT3) was greater for ENH primarily during the milk-fed period and corresponded with greater serum insulin. The greater reticuloruminal mass in calves fed ENH postweaning underscores the importance of feeding high-quality starter and indicates that fermentability of the diet, by providing metabolic fuel for ruminal epithelial cells, is a primary driver of ruminal development postweaning. From a mechanistic standpoint, the 7 -fold increase in expression of the nuclear receptor PPARD ( 40-fold more abundant than PPARA) suggests a key role in controlling biological processes driving ruminal epithelial cell development. Elucidating ligands of PPARD may provide the means for nutritional regulation of rumen development.

Key words: ruminal epithelium, rumen development, calf

\section{INTRODUCTION}

Early and optimal development of the rumen is required to ensure animal health, productivity, and economic benefit for producers. The effect of plane of nutrition on rumen development has been studied previously (Stobo et al., 1966). Recent work has focused more on quantitative aspects of feeding high protein diets in "accelerated" feeding programs to manipulate rates of growth (Diaz et al., 2001; Bartlett et al., 2006). However, metabolic changes in ruminal epithelial tissue that occur in response to plane of nutrition in accelerated feeding programs remain to be determined.

In the first few weeks of life, extensive physical and metabolic adaptations occur in the rumen, including changes in organ size, number and size of rumen papillae, and development of muscular tissue (Van Soest, 1994). Early consumption of starter promotes rumen development by stimulating the fermentation process, and thus the production of VFA. In enhanced early 
nutrition management programs, the supplementation of higher quality starters (e.g., with greater CP content) may help in providing limiting nutrients due to the expected lower starter intake. Starters with higher contents of degradable CP likely lead to more rapid production of VFA, branched-chain VFA, and ammonia. Under those conditions, ruminal tissue metabolism likely adapts through a series of mechanisms, including changes at the level(s) of mRNA, protein, and enzyme activity.

To understand changes in energy metabolism of developing ruminal epithelium with respect to plane of nutrition and age, various aspects of metabolism have been explored, including ketogenesis (Lane et al., 2002), VFA absorption, butyrate and glucose oxidation (Baldwin and Jesse, 1992), propionate metabolism (Weigand et al., 1972), long-chain fatty acid (LCFA) metabolism (Jesse et al., 1992), and cell proliferation (Shen et al., 2004). In addition, via in vitro and short-term experiments, insulin-like growth factor-1 (IGF1) or insulin has been reported to induce ruminal epithelial cell proliferation (Baldwin, 1999). Enhanced early nutrition programs could likely induce changes in mRNA expression that may play a role in promoting efficient growth of ruminal epithelium.

Our general hypothesis was that both plane of nutrition and stage of growth would alter mRNA expression of genes associated with metabolism and transport in the ruminal epithelium. Therefore, to gain a more complete understanding of the overall process of ruminal cell metabolism and proliferation, and thus its development, we used quantitative PCR (qPCR) as a tool for in-depth study of the relationships between selected genes and blood metabolites in response to enhanced nutrition from birth through the first weeks after weaning. On the basis of previous work mostly with mature ruminants (Connor et al., 2010) and additional targets of interest, we focused on expression patterns of genes involved in various metabolic pathways, intracellular $\mathrm{pH}$ control, and cell proliferation in calves.

\section{MATERIALS AND METHODS}

\section{Animals and Sampling}

Samples used in this study were a subset obtained from a larger experiment (Stamey, 2008). All animal procedures were conducted under protocols approved by the University of Illinois Institutional Animal Care and Use Committee (protocol 04151). Specific details on feeding, management, and sample collection have been reported previously (Stamey, 2008). Briefly, calves were fed reconstituted control milk replacer (MR; $20 \%$ CP, $20 \%$ fat) at a rate of $1.25 \%$ of birth BW as solids per calf or a high-protein MR (ENH; $28.5 \%$ CP, $15 \%$ fat) at a rate of approximately $2 \%$ of BW (divided into 2 feedings daily). During wk 6, enhanced MR was fed at $1 \%$ of BW and control MR was fed at $0.625 \%$ of birth BW once daily. These treatments were given from d 3 through d 42 of life, after which calves were weaned (Table 1 and Figure 1). Calves in the control group were fed a control starter formulated to contain $18 \%$ CP (as-fed basis) through d 70 of life. In contrast, calves in ENH were fed a starter formulated to contain $22 \%$ CP (as-fed basis) through d 70 of life. Groups of calves in control and ENH were harvested at $35 \mathrm{~d}$ (wk 5; before the last week of MR feeding) and at $71 \mathrm{~d}$ (wk 10) of life at the Meat Sciences Laboratory at the University of Illinois. Ruminal tissue samples from the ventral sac of the rumen from 5 animals each in control and ENH at wk 5 and wk 10 were used for transcript profiling. Details of the procedure for blood sampling and metabolite and insulin analyses are given in the supplementary material (available online at http:// www.journalofdairyscience.org/).

\section{RNA Extraction, PCR, and Design and Evaluation of Primers}

Total RNA in samples was extracted using established protocols in our laboratories (Loor et al., 2005). Briefly, ruminal tissue was weighed $(\sim 0.3-0.5 \mathrm{~g})$ and placed immediately inside a $15-\mathrm{mL}$ centrifuge tube (cat. no. 430052, Corning Inc., Corning, NY) with $1 \mu \mathrm{L}$ of linear acrylamide (cat. no. 9520, Ambion, Austin, TX) as a co-precipitant, and $5 \mathrm{~mL}$ of ice-cold Trizol reagent (Life Technologies Corp., Carlsbad, CA). Tissue was then homogenized. Genomic DNA was removed from RNA with DNase using RNeasy Mini Kit columns (Qiagen, Hilden, Germany). The concentration of RNA was measured using a Nano-Drop ND-1000 spectrophotometer (Nano-Drop Technologies, Wilmington, DE). The purity of RNA (ratio of absorbance at 260 and $280 \mathrm{~nm}$; $\mathrm{A}_{260} / \mathrm{A}_{280}$ ) for all samples was above 1.81. Quality of RNA was evaluated using the Agilent Bioanalyzer system (Agilent Technologies, Santa Clara, CA). Samples used had an RNA integrity number $>8.0$. A portion of the RNA was diluted to $100 \mathrm{mg} / \mathrm{L}$ using DNase/ RNase-free water before reverse transcription.

\section{qPCR Analysis}

For qPCR analysis, cDNA was synthesized using 100 ng of RNA, $1 \mu \mathrm{g}$ of dT18 (Operon Biotechnologies, Huntsville, AL), $1 \mu \mathrm{L}$ of $10 \mathrm{mmol} / \mathrm{L}$ dNTP mix (Life Technologies Corp.), $1 \mu \mathrm{L}$ of random primer $\mathrm{p}(\mathrm{dN})_{6}$ (cat. no 11034731001, Roche, Indianapolis, IN), and $10 \mu \mathrm{L}$ of DNase/RNase-free water. The mixture was incubated at $65^{\circ} \mathrm{C}$ for $5 \mathrm{~min}$ and kept on ice for $3 \mathrm{~min}$. 
Table 1. Daily intake of milk replacer and starter, tissue weights, and blood metabolites in calves fed reconstituted control milk replacer $(20 \% \mathrm{CP}, 20 \%$ fat) at a rate of $1.25 \%$ of birth BW as solids per calf or a high-protein milk replacer (ENH; $28.5 \% \mathrm{CP}, 15 \%$ fat) at a rate of approximately $2 \%$ of BW

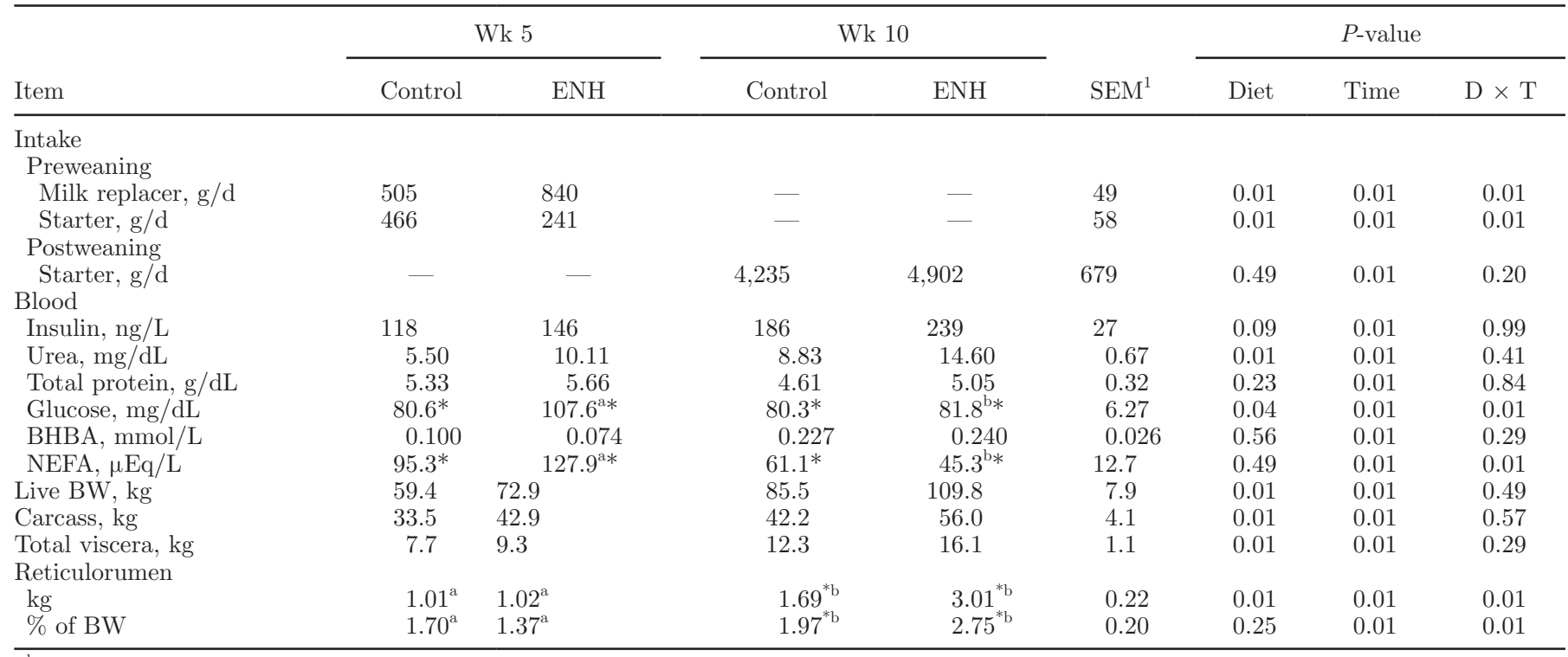

${ }^{\mathrm{a}, \mathrm{b}}$ Means with different superscripts denote significant interactions due to diet $\times$ time $(\mathrm{D} \times \mathrm{T})$ between weeks at $P<0.10$.

${ }^{1} \mathrm{SEM}=$ the largest standard error of the mean.

*Means with symbols differ due to $\mathrm{D} \times \mathrm{T}$ within weeks at $P<0.10$.

A total of $6 \mu \mathrm{L}$ of master mix composed of $4.5 \mu \mathrm{L}$ of $5 \times$ First-Strand buffer, $1 \mu \mathrm{L}$ of $0.1 M$ dithiothreitol, $0.25 \mu \mathrm{L}(50 \mathrm{U})$ of SuperScript III RT (Life Technologies Corp.), and $0.25 \mu \mathrm{L}$ of RNase Inhibitor (10 U, Promega, Madison, WI) was added. The reaction was performed in an Eppendorf Mastercycler Gradient (Eppendorf, Hauppauge, NY) using the following temperature program: $25^{\circ} \mathrm{C}$ for $5 \mathrm{~min}, 50^{\circ} \mathrm{C}$ for $60 \mathrm{~min}$, and $70^{\circ} \mathrm{C}$ for 15 min. cDNA was then diluted 1:4 (vol/vol) with DNase/ RNase-free water.

Quantitative PCR was performed using $4 \mu \mathrm{L}$ of diluted cDNA (dilution 1:4) combined with $6 \mu \mathrm{L}$ of a mixture composed of $5 \mu \mathrm{L} 1 \times$ SYBR Green master mix (Life Technologies Corp.), $0.4 \mu \mathrm{L}$ each of $10 \mu M$ forward and reverse primers, and $0.2 \mu \mathrm{L}$ of DNase/RNase-free water in a MicroAmp Optical 384-Well Reaction Plate (Life Technologies). Each sample was run in triplicate and a 6-point relative standard curve (made from a pool of cDNA from all rumen samples) plus the nontemplate control was used (User Bulletin \#2, Life Technologies). The reactions were performed in an ABI Prism 7900 HT SDS instrument (Life Technologies) using the following conditions: $2 \mathrm{~min}$ at $50^{\circ} \mathrm{C}, 10 \mathrm{~min}$ at $95^{\circ} \mathrm{C}, 40$ cycles of $15 \mathrm{~s}$ at $95^{\circ} \mathrm{C}$ (denaturation), and $1 \mathrm{~min}$ at $60^{\circ} \mathrm{C}$ (annealing + extension). The presence of a single PCR product was verified by the dissociation protocol using incremental temperatures to $95^{\circ} \mathrm{C}$ for $15 \mathrm{~s}$ plus $65^{\circ} \mathrm{C}$ for 15 s. Data were calculated with the 7900 HT Sequence Detection Systems Software (version 2.2.1, Life Technologies). Complete details for selection of internal control genes are presented in the supplementary material (available online at http://www.journalofdairyscience.org/). The chosen genes are grouped according to main biological functions in Tables 2 and 3 (and in the supplemental material).

\section{Statistical Analysis}

Statistical analysis of all data was via ANOVA using the MIXED procedure in SAS (SAS Institute Inc., Cary, NC). A repeated-measures model was used and consisted of time, treatment, and time $\times$ treatment interaction as fixed effects, as well as calf (treatment) as the random effect. An autoregressive covariance structure was used. All means were compared using the PDIFF statement of SAS. Least squares means and standard errors are reported in tables. Significance was declared at $P \leq 0.10$.

\section{RESULTS}

Intake of MR during the preweaning period was greater overall (diet, $P<0.01$; Table 1 ) in calves fed ENH. Intake in those calves increased gradually over time (interaction, $P<0.01$; Figure 1). Despite an increase in voluntary starter intake over time in calves fed $\mathrm{ENH}$, those calves consumed less starter overall (diet, $P$ $<0.01$; Table 1) during the preweaning period (Figure 1). Calves fed control consumed greater amounts of starter during the preweaning period. 

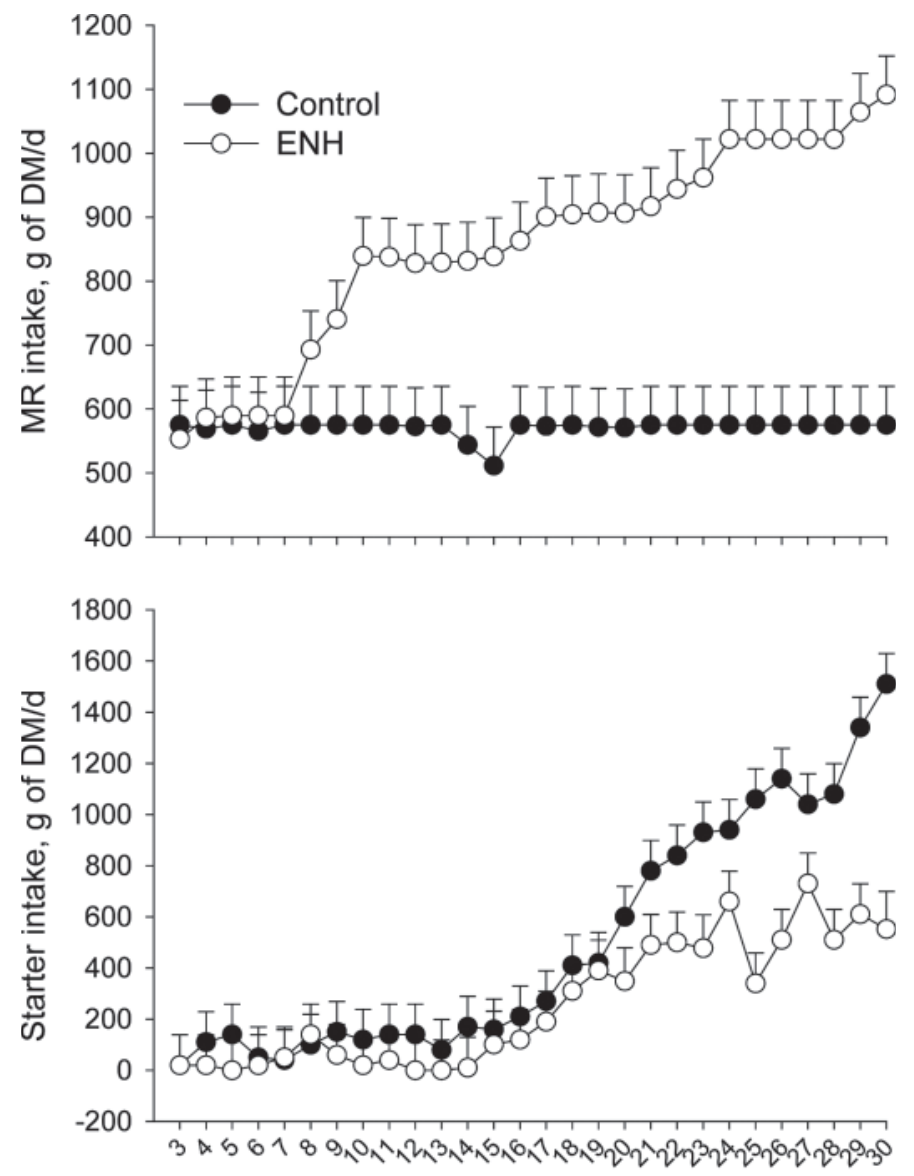

Day on experiment

Figure 1. Daily intake of milk replacer and starter in calves fed reconstituted control milk replacer (MR; $20 \% \mathrm{CP}, 20 \%$ fat) at a rate of $1.25 \%$ of birth BW as solids per calf or a high-protein MR (ENH $28.5 \% \mathrm{CP}, 15 \%$ fat) at a rate of approximately $2 \%$ of BW. A significant $(P<0.01)$ interaction effect was found for both MR and starter intake (see Table 1). Error bars show standard errors.

Concentrations of metabolites and insulin in blood and tissue weights are summarized in Table 1. Serum concentration of insulin was greater $(P=0.09)$ overall in response to feeding ENH compared with control (193 $\mathrm{ng} / \mathrm{L}$ vs. $179 \mathrm{ng} / \mathrm{L})$ and increased $(P<0.05)$ over time. An interaction effect was observed for the concentration of glucose (107.6 vs. $80.6 \mathrm{mg} / \mathrm{dL})$, BUN (10.11 vs. $5.50 \mathrm{mg} / \mathrm{dL}$ ), and NEFA (127.9 vs. $95.3 \mu \mathrm{Eq} / \mathrm{L})$ due primarily to greater concentrations at wk 5 in calves fed ENH. The effect of ENH on BUN persisted at wk 10 of the study (14.60 vs. $8.83 \mathrm{mg} / \mathrm{dL}$; Table 1$)$. Serum BHBA concentration increased significantly (time $P=$ $0.01)$ over time in the blood. An interaction effect $(P=$ 0.01 ) was found for reticulorumen mass due to greater weights in calves fed ENH compared with control at wk 10 (Table 1). Mean reticulorumen weight at wk 10 was $1.8 \mathrm{~kg}$ compared with $2.7 \mathrm{~kg}$ for calves fed control MR plus control starter or ENH MR plus ENH starter, respectively (Table 1 ). When reticulorumen weight was expressed as percentage of $\mathrm{BW}$, an interaction $(P<$ 0.01) was observed for reticulorumen weight at wk 10 in calves fed ENH. Specific details on nutrient composition of the diet have been reported previously (Stamey, 2008) and are not emphasized here.

The genes analyzed were grouped according to their respective biochemical pathways (Table 1). Among short-chain fatty acid transporters, we evaluated the gene expression of 3 monocarboxylate transporters; SLC16A3 (MCT1), SLC16A7 (MCT2), and SLC16A1 (MCT4; Table 2). Only SLC16A7 was observed to be affected significantly by diet $\times$ time $(P=0.02)$ due to greater expression at wk 5 in calves fed ENH (Table 2). Among the genes involved in maintaining intracellular $\mathrm{pH}$, we evaluated mRNA expression of genes encoding CA1, SLC9A2, SLC4A2, SLC26A3, SLC36A1, and $S L C 4 A 4$ (Table 2). Greater mRNA abundance $(\sim 38 \%)$ and significantly higher expression $(P=0.01)$ of $C A 1$ was observed with ENH (Table 2). We found an interaction effect on the expression of $S L C 9 A 2(P=0.09)$ at wk 5 due to lower expression with ENH. A lower expression of SLC4A4 $(P<0.01)$ and SLC36A1 $(P=0.01)$ was observed at wk 5 with ENH (Table 2). Among nutrient transporters, we analyzed the expression of urea transporter U-TB (SLC14A1), whose expression was higher at wk 10 compared with wk 5 (time, $P<0.05$; Table 2).

The mRNA expression of 2 mitochondrial proteins that link mitochondrial ATP production with cellular ATP consumption (i.e., adenine nucleotide translocase), SLC25A4 and SLC25A5, was also evaluated. We observed a significant diet $\times$ time effect $(P=0.04)$ for $S L C 25 A 4$ because of a marked decrease in expression between wk 5 and wk 10 in ENH (Table 2). Among recently identified G-coupled protein receptors for short-chain fatty acids, we evaluated the expression of FFAR1 (GPR43), FFAR2 (GPR42), and FFAR3 (GPR41). Despite previous evidence of their expression, we were unable to detect any of the above receptors in ruminal epithelial tissue. Data for these receptors are not reported here due to the very low abundance (qPCR cycle threshold $>30$ ).

Among ketogenic genes, we found an increase (time, $P<0.05)$ in expression of HMGCS2, HMGCL, and $B D H 1$ over time regardless of diet (Table 2). Only expression of $H M G C L$ was affected $(P=0.09)$ by treatment. Among key genes associated with cholesterolgenesis, expression of the rate-limiting enzyme $H M G C R$ decreased over time $(P<0.01)$, whereas expression of HMGCS1 increased $(P<0.01)$. However, lower expression was observed for $H M G C R$ due to feeding ENH ( $P$ $<0.01$; Table 2).

In the pyruvate metabolism pathway, we evaluated the expression of pyruvate carboxylase $(P C)$ and pyru- 
Table 2. Relative mRNA expression and overall percentage mRNA abundance among genes investigated in metabolic pathways ${ }^{1}$

\begin{tabular}{|c|c|c|c|c|c|c|c|c|c|}
\hline \multirow[b]{2}{*}{ Gene } & \multirow[b]{2}{*}{$\%$ mRNA } & \multicolumn{2}{|c|}{ Wk 5} & \multicolumn{2}{|c|}{ Wk 10} & \multirow[b]{2}{*}{ SEM } & \multicolumn{3}{|c|}{$P$-value } \\
\hline & & Control & $\mathrm{ENH}$ & Control & $\mathrm{ENH}$ & & Diet & Time & $\mathrm{D} \times \mathrm{T}$ \\
\hline \multicolumn{10}{|l|}{ Intracellular activation of VFA before metabolism } \\
\hline Acyl-CoA synthetase short-chain $(A C S S 1)^{2}$ & 0.10 & 0.04 & 0.34 & -0.20 & -0.41 & 0.25 & 0.82 & 0.01 & 0.20 \\
\hline \multicolumn{10}{|l|}{ Ketogenesis } \\
\hline 3-Hydroxy-3-methylglutaryl-CoA synthase $2(H M G C S 2)^{3}$ & 40.1 & 0.76 & 0.64 & 1.06 & 0.96 & 0.10 & 0.22 & 0.01 & 0.92 \\
\hline 3 -Hydroxybutyrate dehydrogenase, type $1(B D H 1)^{2}$ & 1.34 & -0.09 & -0.34 & 0.19 & 0.17 & 0.12 & 0.17 & 0.01 & 0.29 \\
\hline 3-Hydroxymethyl-3-methyl glutaryl-CoA lyase $(H M G C L)^{2}$ & 0.39 & -0.71 & -0.31 & 0.20 & 0.39 & 0.19 & 0.09 & 0.01 & 0.55 \\
\hline Acetoacetyl-CoA synthetase $(A A C S)^{2}$ & 0.02 & -0.12 & 0.006 & -0.12 & 0.22 & 0.09 & 0.86 & 0.13 & 0.17 \\
\hline Acetyl-CoA acyl transferase $1(A C A T 1)^{2}$ & 1.42 & -0.18 & -0.47 & -0.29 & -0.27 & 0.15 & 0.31 & 0.76 & 0.24 \\
\hline \multicolumn{10}{|l|}{ Cholesterogenesis } \\
\hline 3-Hydroxy-3-methylglutaryl-CoA reductase $(H M G C R)^{3}$ & 0.07 & 0.33 & 0.12 & 0.16 & 0.07 & 0.05 & 0.01 & 0.01 & 0.19 \\
\hline 3-Hydroxy-3-methylglutaryl-CoA synthase $1\left(\right.$ HMGCS1) ${ }^{2}$ & 0.17 & -0.002 & -0.27 & 0.08 & 0.03 & 0.08 & 0.04 & 0.01 & 0.17 \\
\hline \multicolumn{10}{|l|}{ Pyruvate metabolism and TCA cycle flux } \\
\hline Glutamate dehydrogenase $1(G L U D 1)^{2}$ & 0.15 & 0.28 & -0.18 & -0.08 & -0.15 & 0.19 & 0.13 & 0.33 & 0.27 \\
\hline Isocitrate dehydrogenase $1 \mathrm{NADP}+\left(\right.$ soluble) $(I D H 1)^{2}$ & 1.81 & -0.19 & -0.13 & -0.08 & -0.01 & 0.11 & 0.51 & 0.21 & 0.99 \\
\hline Lactate dehydrogenase B (heart; $L D H B)^{2}$ & 0.34 & 0.05 & 0.02 & -0.22 & -0.21 & 0.18 & 0.96 & 0.12 & 0.88 \\
\hline Lactate dehydrogenase A (muscle; LDHA) ${ }^{2}$ & 1.34 & $0.06^{*}$ & $-0.20^{\mathrm{a} *}$ & 0.11 & $0.13^{\mathrm{b}}$ & 0.07 & 0.03 & 0.01 & 0.02 \\
\hline Malate dehydrogenase 2, NAD (mitochondrial) $(M D H 2)^{2}$ & 1.51 & -0.28 & -0.13 & -0.07 & -0.02 & 0.13 & 0.41 & 0.19 & 0.68 \\
\hline Mitochondrial (aspartate aminotransferase 2) $\left(\right.$ GOT2) ${ }^{2}$ & 0.12 & -0.25 & 0.01 & 0.32 & 0.19 & 0.15 & 0.61 & 0.01 & 0.13 \\
\hline Oxoglutarate dehydrogenase (lipoamide) $(O G D H)^{2}$ & 1.02 & -0.15 & -0.08 & -0.12 & -0.07 & 0.09 & 0.48 & 0.82 & 0.94 \\
\hline Pyruvate carboxylase $(P C)^{3}$ & 0.003 & $0.81^{*}$ & $1.49^{\mathrm{a} *}$ & 0.96 & $1.01^{\mathrm{b}}$ & 0.19 & 0.04 & 0.35 & 0.08 \\
\hline Pyruvate dehydrogenase lipoamide $\alpha 1(\text { PDHA1 })^{3}$ & 0.65 & 0.89 & 0.83 & 0.81 & 0.83 & 0.06 & 0.73 & 0.37 & 0.39 \\
\hline \multicolumn{10}{|l|}{ Propionate entry into tricarboxylic acid (TCA) cycle } \\
\hline Propionyl-CoA carboxylase $(P C C A)^{2}$ & 0.24 & -0.06 & -0.14 & 0.22 & 0.08 & 0.13 & 0.03 & 0.01 & 0.64 \\
\hline \multicolumn{10}{|l|}{ Long-chain FA oxidation } \\
\hline Acyl-CoA dehydrogenase, short/branched chain $(A C A D S B)^{2}$ & 1.72 & 0.03 & -0.24 & 0.06 & -0.33 & 0.17 & 0.03 & 0.83 & 0.69 \\
\hline Acyl-CoA dehydrogenase family, member $9(A C A D V L)^{2}$ & 0.02 & 0.21 & 0.37 & 0.01 & 0.11 & 0.08 & 0.07 & 0.01 & 0.65 \\
\hline Acyl-CoA dehydrogenase, $\mathrm{C}-2$ to $\mathrm{C}-3$ short chain $(A C A D S)^{2}$ & 2.53 & -0.13 & -0.12 & -0.05 & 0.10 & 0.18 & 0.49 & 0.18 & 0.57 \\
\hline Carnitine palmitoyl-transferase $1 \mathrm{~A}(C P T 1 A)^{2}$ & 0.78 & 0.24 & 0.51 & 0.13 & -0.12 & 0.18 & 0.96 & 0.03 & 0.12 \\
\hline Carnitine palmitoyl-transferase 1B $(C P T 1 B)^{2}$ & 0.008 & -0.07 & 0.11 & -0.33 & -0.40 & 0.5 & 0.82 & 0.14 & 0.63 \\
\hline Fibroblast growth factor $21(F G F 21)^{3}$ & 0.0003 & 1.89 & 1.57 & 0.41 & 0.71 & 0.70 & 0.71 & 0.03 & 0.88 \\
\hline \multicolumn{10}{|l|}{ Transcriptional regulation } \\
\hline Angiopoietin-like $4(A N G P T L 4)^{2}$ & 0.03 & -0.04 & 0.09 & -0.27 & -0.29 & 0.12 & 0.61 & 0.01 & 0.48 \\
\hline Peroxisome proliferator-activated receptor- $\alpha(P P A R A)^{2}$ & 0.007 & 0.84 & 0.11 & -0.13 & -0.44 & 0.26 & 0.06 & 0.01 & 0.47 \\
\hline Peroxisome proliferator-activated receptor- $\delta(P P A R D)^{2}$ & 0.33 & -0.28 & -0.32 & -0.06 & -0.02 & 0.06 & 0.95 & 0.01 & 0.47 \\
\hline Retinoid X receptor- $\alpha(R X R A)^{2}$ & 0.09 & -0.14 & -0.35 & -0.20 & -0.33 & 0.09 & 0.12 & 0.83 & 0.67 \\
\hline Retinoid X receptor- $\beta(R X R B)^{2}$ & 0.08 & -0.21 & -0.006 & -0.14 & -0.02 & 0.27 & 0.32 & 0.79 & 0.89 \\
\hline \multicolumn{10}{|l|}{ Intracellular acid base balance } \\
\hline Carbonic anhydrase $1(C A 1)^{2}$ & 38.01 & -0.36 & 0.01 & -0.26 & 0.008 & 0.14 & 0.01 & 0.69 & 0.68 \\
\hline \multicolumn{10}{|l|}{ Transporters } \\
\hline Anion exchanger isoform $2(S L C 4 A 2)^{2}$ & 0.05 & -0.09 & 0.09 & -0.15 & -0.08 & 0.07 & 0.05 & 0.06 & 0.33 \\
\hline Chloride anion exchanger $(S L C 26 A 3)^{2}$ & 0.71 & -3.37 & -2.49 & -3.08 & -2.94 & 0.38 & 0.06 & 0.84 & 0.13 \\
\hline Proton-coupled amino acid symporter $(S L C 36 A 1)^{2}$ & 0.003 & 0.37 & -0.16 & -0.41 & -0.65 & 0.28 & 0.12 & 0.01 & 0.56 \\
\hline $\mathrm{Na}^{+} / \mathrm{HCO}_{3}{ }^{-}$cotransporter $\left(S L C 4 A_{4}\right)^{2}$ & 0.005 & 0.35 & 0.19 & -0.97 & -1.55 & 0.27 & 0.16 & 0.01 & 0.43 \\
\hline $\mathrm{Na}^{+} / \mathrm{H}^{+}$exchanger $2(S L C 9 A 2)^{3}$ & 0.55 & $1.15^{*}$ & $0.63^{\mathrm{a} *}$ & 1.40 & $1.31^{\mathrm{b}}$ & 0.14 & 0.02 & 0.01 & 0.09 \\
\hline Monocarboxylic acid transporter $1(S L C 16 A 1)^{3}$ & 1.07 & 0.96 & 0.86 & 0.99 & 1.10 & 0.13 & 0.98 & 0.24 & 0.37 \\
\hline Monocarboxylic acid transporter $4(S L C 16 A 3)^{2}$ & 0.71 & 0.19 & 0.40 & 0.22 & 0.21 & 0.11 & 0.35 & 0.41 & 0.27 \\
\hline Monocarboxylic acid transporter $2(S L C 16 A 7)^{2}$ & 0.11 & $-0.02^{*}$ & $0.53^{\mathrm{a} *}$ & -0.28 & $-0.39^{\mathrm{b}}$ & 0.16 & 0.12 & 0.01 & 0.02 \\
\hline Urea transporter $1(S L C 14 A 1)^{2}$ & 0.03 & -2.4 & -0.67 & 0.20 & 0.11 & 1.00 & 0.37 & 0.06 & 0.32 \\
\hline
\end{tabular}




\begin{tabular}{|c|c|c|c|c|c|c|c|c|c|}
\hline \multirow[b]{2}{*}{ Gene } & \multirow[b]{2}{*}{$\%$ mRNA } & \multicolumn{2}{|c|}{ Wk 5} & \multicolumn{2}{|c|}{ Wk 10} & \multirow[b]{2}{*}{ SEM } & \multicolumn{3}{|c|}{$P$-value } \\
\hline & & Control & $\mathrm{ENH}$ & Control & $\mathrm{ENH}$ & & Diet & Time & $\mathrm{D} \times \mathrm{T}$ \\
\hline ADP-ATP carrier protein $1(S L C 25 A 4)^{2}$ & 0.24 & -0.25 & $-0.04^{\mathrm{a}}$ & -0.36 & $-0.51^{\mathrm{b}}$ & 0.09 & 0.77 & 0.01 & 0.04 \\
\hline ADP-ATP carrier protein $2(S L C 25 A 5)^{3}$ & 0.48 & 0.82 & 0.98 & 1.04 & 0.94 & 0.10 & 0.75 & 0.31 & 0.15 \\
\hline
\end{tabular}



$\leqslant \quad{ }^{1}$ The percentage mRNA abundance was calculated as $\left\{\left[\left(1 /\right.\right.\right.$ Efficiency $\left.^{\Delta \mathrm{Ct}}\right)$ specific gene/sum $\left(1 /\right.$ Efficiency $\left.^{\Delta \mathrm{Ct}}\right)$ all genes $\left.] \times 100\right\}($ Bionaz et al., 2012$)$. ENH $=$ high-protein milk replacer treatment.

G $\quad{ }^{2}$ Data were not normally distributed.

Z $\quad{ }^{3}$ Data were normally distributed.

+ Means with symbols differ due to $\mathrm{D} \times \mathrm{T}$ within week $(P<0.10)$.

Table 3. Relative mRNA expression and overall percentage mRNA abundance among genes in insulin signaling pathway ${ }^{1}$

\begin{tabular}{|c|c|c|c|c|c|c|c|c|c|}
\hline \multirow[b]{2}{*}{ Gene } & \multirow[b]{2}{*}{$\% \mathrm{~m}$ RNA } & \multicolumn{2}{|c|}{ Wk 5} & \multicolumn{2}{|c|}{ Wk 10} & \multirow[b]{2}{*}{ SEM } & \multicolumn{3}{|c|}{$P$-value } \\
\hline & & Control & ENH & Control & $\mathrm{ENH}$ & & Diet & Time & $\mathrm{D} \times \mathrm{T}$ \\
\hline $\mathrm{IGF}-1(I G F 1)^{2}$ & 0.12 & -0.20 & 0.04 & -0.75 & -0.31 & 0.20 & 0.14 & 0.05 & 0.67 \\
\hline v-akt murine thymoma viral oncogene $1(A K T 1)^{2}$ & 1.35 & 0.17 & 0.61 & 0.08 & 0.51 & 0.33 & 0.15 & 0.76 & 0.97 \\
\hline v-akt murine thymoma viral oncogene $2(A K T 2)^{3}$ & 0.03 & 0.85 & 1.04 & 0.89 & 0.89 & 0.12 & 0.42 & 0.62 & 0.42 \\
\hline v-akt murine thymoma viral oncogene $3(A K T 3)^{2}$ & 0.57 & $-0.25^{*}$ & $0.06^{\mathrm{a} *}$ & $-0.05^{*}$ & $-0.32^{\mathrm{b} *}$ & 0.96 & 0.76 & 0.32 & 0.01 \\
\hline Forkhead box O1 $(F O X O 1)^{2}$ & 0.07 & -0.04 & 0.22 & -0.09 & 0.03 & 0.12 & 0.03 & 0.19 & 0.42 \\
\hline IGF-1 receptor $(I G F 1 R)^{3}$ & 0.09 & 0.94 & 1.01 & 1.20 & 0.99 & 0.11 & 0.49 & 0.19 & 0.15 \\
\hline Insulin receptor $(I N S R)^{2}$ & 0.05 & -0.27 & 0.11 & -0.09 & 0.008 & 0.17 & 0.04 & 0.82 & 0.17 \\
\hline Phosphoinositide-3-kinase, $\alpha(P I K 3 C A)^{2}$ & 0.19 & -0.12 & -0.03 & -0.15 & 0.03 & 0.22 & 0.44 & 0.96 & 0.79 \\
\hline Mammalian target of rapamycin $(m T O R)^{2}$ & 0.01 & 1.58 & 0.83 & 0.46 & 0.26 & 0.23 & 0.02 & 0.05 & 0.18 \\
\hline
\end{tabular}

${ }_{\mathrm{a}, \mathrm{b}}$ Means with different superscripts denote significant interactions due to diet $\times$ time $(\mathrm{D} \times \mathrm{T})$ between weeks $(P<0.10)$.

${ }^{1}$ The percentage mRNA abundance was calculated as $\left\{\left[\left(1 /\right.\right.\right.$ Efficiency $\left.^{\Delta \mathrm{Ct}}\right)$ specific gene/sum $\left(1 /\right.$ Efficiency $\left.^{\Delta \mathrm{Ct}}\right)$ all genes $\left.] \times 100\right\}($ Bionaz et al., 2012$)$. ENH $=$ high-protein milk replacer treatment.

${ }^{2}$ Data were not normally distributed.

${ }^{3}$ Data were normally distributed.

*Means with symbols differ due to $\mathrm{D} \times \mathrm{T}$ within week $(P<0.10)$. 
indicated extensive protein and AA degradation; that is, preweaning from tissue metabolism and postweaning from ruminal and peripheral tissue metabolism. Overall, these changes agree with the longitudinal responses in intake of MR and starter that we observed.

Increasing the dietary CP concentration (14 to $26 \%$ of $\mathrm{DM}$ ) or feeding rate (1.25 to $1.75 \%$ ) did not affect serum NEFA in previous studies (Blome et al., 2003; Bartlett et al., 2006). Greater intake of fat from the ENH diet during the preweaning period likely accounted for the greater concentration of blood NEFA at wk 5 . Thus, the significant decrease in blood NEFA concentration with age reflected the lower intake of fat postweaning; that is, the amount of fat in starter was negligible.

A significant increase in serum BHBA concentration in blood over time suggested normal ruminal development without a significant effect of diet. In contrast to our study, BHBA concentrations were greater in calves fed $28 \% \mathrm{CP}$ and $20 \%$ fat MR plus $20.5 \% \mathrm{CP}$ starter for a period of $42 \mathrm{~d}$ compared with calves fed $20 \% \mathrm{CP}$ and $20 \%$ fat MR plus $20.5 \%$ CP starter at $10 \%$ of BW (Bridges, 2009). Differences in the response of BHBA to diet may be associated with a greater percentage of cracked corn (43.7\%, as-fed basis) in the above study compared with ours (22.5 vs. $21.5 \%$ in control vs. ENH starter), which may have led to more butyric acid to produce BHBA.

Bartlett et al. (2006) did not observe any effect of increasing dietary $\mathrm{CP}$ content on organ weights (gastrointestinal tract, liver, heart, and kidneys) but increased feeding rates from 1.25 to $1.75 \%$ of $\mathrm{BW}$ led to greater organ weights (Bartlett et al., 2006). In contrast, a linear relationship was observed between total visceral weight (including gastrointestinal tract) and increasing dietary CP content (Blome et al., 2003), which may explain the greater reticulorumen weight at wk 10 for calves ENH MR plus ENH starter (2.75 vs. $1.97 \%$ of BW).

\section{VFA Absorption}

Greater expression of $S L C 16 A \%$, which is involved in VFA transport at low concentrations (Sepponen et al., 2003), was suggestive of lower VFA production during the milk-fed period (i.e., by wk 5) in the rumen of calves fed ENH. Although we did not measure ruminal VFA concentrations, a previous study (Bridges, 2009) found numerically lower concentrations of total ruminal VFA after 4 wk in calves fed a high-protein MR (28\% CP plus $15 \%$ fat) plus starter (20\% CP plus $20 \%$ fat) at a greater MR feeding rate than calves fed conventional MR (20\% CP plus $20 \%$ fat) and starter at lower MR feeding rate. Koho et al. (2005) found a higher protein expression of $S L C 16 A 3$ in free-ranging reindeers compared with concentrate-fed $(19.3 \% \mathrm{CP})$ reindeers. Because starter intake across treatments differed in both the milk-fed and postweaning period, the lack of change in expression of these major transporters seems to suggest that uptake across the rumen wall may not have been limited by amount of transporters in the plasma membrane.

The $\mathrm{HCO}_{3}{ }^{-}$and $\mathrm{H}^{+}$produced within the ruminal epithelium as a result of hydration of $\mathrm{CO}_{2}$ and dehydration of bicarbonate by activity of carbonic anhydrase $(C A 1)$ is, by far, the main mechanism regulating intracellular pH (Carter, 1971; Wang et al., 1996). In addition to CA1, secretion of $\mathrm{HCO}_{3}{ }^{-}$from ruminal epithelial cells into the lumen of the rumen plays a crucial role in maintaining intraluminal $\mathrm{pH}$ and absorption of ammonia and VFA (Bödeker et al., 1992). Besides buffering the intraluminal $\mathrm{pH}, \mathrm{HCO}_{3}{ }^{-}$export also helps against the increase in intracellular $\mathrm{pH}$ that could result due to proton extrusion via sodium-proton exchangers (NHE; Muller et al., 2002; Aschenbach et al., 2011). Bilk et al. (2005) have demonstrated the mRNA expression in ruminal epithelium of 3 proteins known to be involved in $\mathrm{HCO}_{3}{ }^{-}$transport: SLC4A2 (AE2), SLC36A1 (PAT1), and SLC26A3 (DRA).

Greater percentage mRNA abundance $(\sim 38 \%)$ and significantly higher expression of $C A 1$ due to ENH suggested a role in transmucosal ammonia flux (Bödeker et al., 1992). As more ammonia is generated due to ruminal degradation of dietary protein, high rates of ammonia absorption are required and these are dependent on the conversion of $\mathrm{HCO}_{3}{ }^{-}$to $\mathrm{CO}_{2}$ as well as deprotonation of VFA (Bödeker et al., 1992). The interaction we observed for SLC9A2 was indicative of potential differences in starter intake and resulting fermentation; that is, greater for control at wk 5 but greater for ENH at wk 10. As the cytosol becomes acidified due to VFA uptake, the SLC9A2 (NHE2) isoform of the $\mathrm{Na}^{+} /$ $\mathrm{H}^{+}$exchanger helps maintain intracellular $\mathrm{pH}$ through $\mathrm{H}^{+}$export (Graham et al., 2007). After intracellular acidification by VFA, greater expression of SLC9A2 in calves fed ENH may have allowed for proton export and $\mathrm{HCO}_{3}{ }^{-}$import as shown in Figure 2. The decrease in expression with time for SLC4A4 and SLC36A1 regardless of diet was indicative of less reliance on $\mathrm{HCO}_{3}{ }^{-}$ secretion from epithelial cells into the lumen (Ikuma et al., 2003; Bilk et al., 2005). The SLC4A2 transporter is found in the basolateral membrane of rat distal colon epithelial cells (Ikuma et al., 2003) and may be involved in $\mathrm{HCO}_{3}{ }^{-}$secretion between the ruminal epithelium and the blood, as shown in Figure 1. 


\section{Ketogenesis}

Ketogenesis is a hallmark of metabolic development of ruminal epithelium tissue (Lane et al., 2002). The mature ruminal epithelium captures the majority of its energy from the oxidation of VFA. More than $90 \%$ of butyrate produced because of microbial fermentation is oxidized and used for ketogenesis. All the ketogenic enzymes except ACAT1 and AACS increased over time; that is, as ruminal tissue developed and grew in mass. We are unaware of previous work demonstrating longitudinal changes in expression of these ketogenic enzymes except for $A C A T$. Our result with $A C A T 1$ was opposite from that reported in a previous study reporting increased expression of $A C A T$ (a human cDNA was used for Northern blots) with age in milk-fed and conventionally reared lambs (Lane et al., 2002).

Relative percentage mRNA abundance of HMGCS2 (mitochondrial isoform) accounted for approximately $40 \%$ of the total genes examined, which underscored its central role in coordinating ruminal ketogenic flux as it does in liver. The increase in blood BHBA concentration with age likely corresponds to an increase in activity of HMGCS2, the rate-limiting mitochondrial

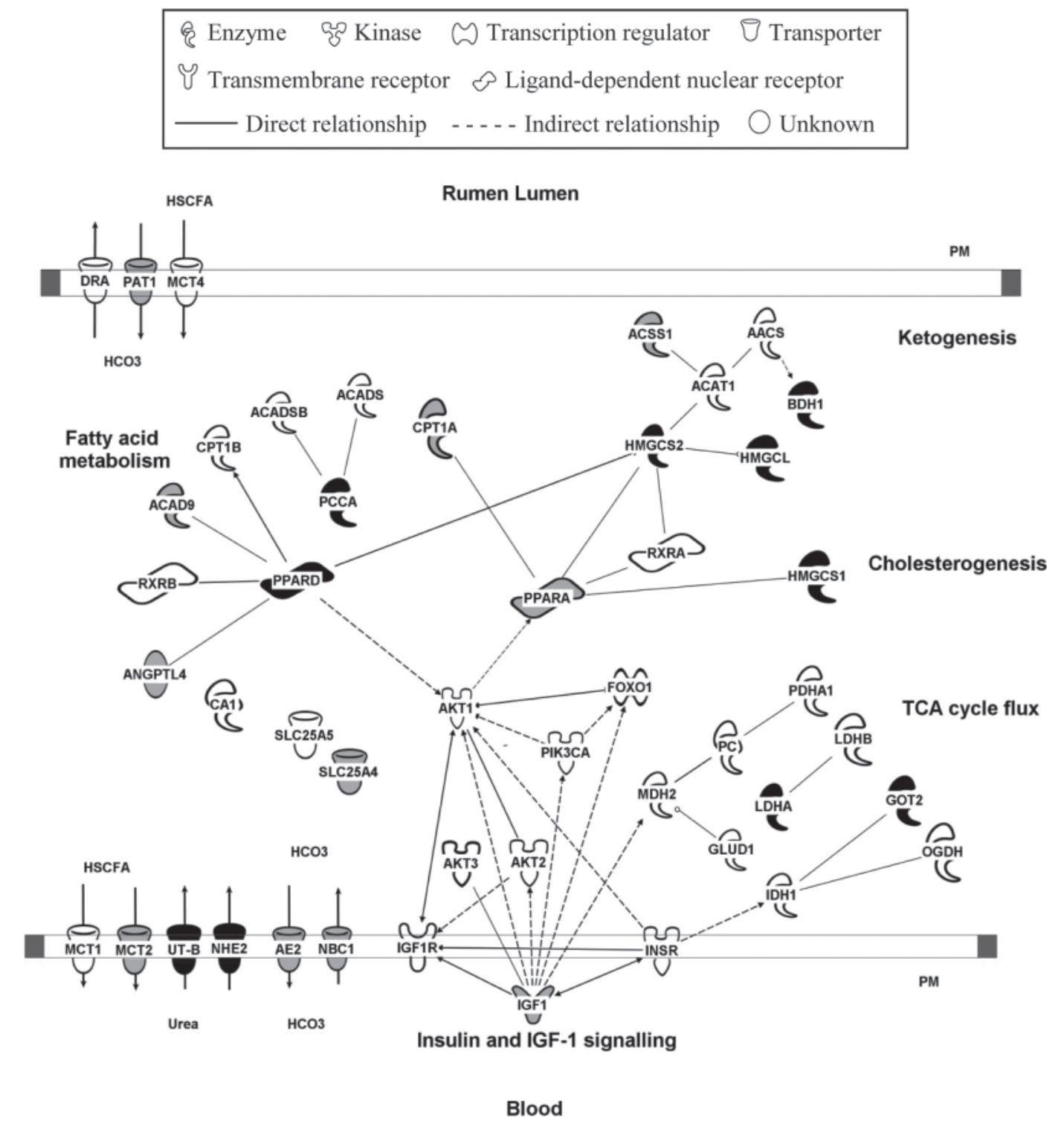

Figure 2. Summary of gene networks in ruminal epithelium at wk 10 compared with wk 5 . The relationships depicted are from the most current information in the Ingenuity Pathway Analysis knowledge base. Upregulated genes are shown (black to gray background according to the level of expression from Tables 2 and 3; black color (upregulated) to light gray color (downregulated). Genes with white-colored background were not affected significantly by time. Gene descriptions can be found in Tables 2 and $3 ; \mathrm{HCO}_{3}=$ bicarbonate; $\mathrm{PM}=$ plasma membrane. 
enzyme in the ketogenic pathway. Lane et al. (2002) also observed a parallel increase in $H M G C S$ mRNA expression (a human cDNA was used for Northern blots) and BHBA production in ruminal epithelial cells from 1 to $84 \mathrm{~d}$ of age regardless of diet.

Leighton et al. (1983) reported some activity of HMGCS1 compared with HMGCS2 (mitochondrial isoform) in mature ruminal epithelium of sheep. The greater overall expression of $H M G C R$ and $H M G C S 1$ due to feeding the control diet suggested that cholesterogenesis in ruminal cells might be sensitive to plane of nutrition. 3-Hydroxy-3-methyl-glutaryl-CoA reductase (HMG-CoA reductase; $H M G C R$ ) is a transcriptionally regulated membrane-bound enzyme that catalyzes the rate-limiting step in cholesterol biosynthesis (Burg and Espenshade, 2011). The possibility that HMGCS1 is important not only for cholesterol synthesis but also for extramitochondrial ketogenesis cannot be excluded. Despite the potential for extramitochondrial ketogenesis (proposed in studies with rodents fed carbohydraterich diets), the large percentage mRNA abundance of HMGCS2 $(\sim 40 \%)$ and the low percentage mRNA abundance of HMGCS1 $(<0.2 \%)$ as a proportion of total genes examined points at intramitochondrial ketogenesis as the primary pathway for generating BHBA in ruminal epithelial cells. This presumption is further supported by data from Brunengraber et al. (1978) showing that this pathway was the most quantitatively important in liver of starved rats or when intracellular concentrations of LCFA were high.

3-Hydroxymethyl-3-methylglutaryl-coenzyme (HMG-CoA) can be converted to acetoacetate by HMGCL or it can enter cholesterol biosynthesis via HMGCR. The final step of ketogenesis is the production of BHBA catalyzed by BDH1 (Zammit, 1984). The relative percentage mRNA abundance of ACAT1 (1.43\%), HMGCL (0.37\%), and BDH1 (1.34\%) was substantially lower than HMGCS2. A lower activity of BDH1 as compared with HMGCL and HMGCS in mature ruminal epithelium was observed by Leighton et al. (1983). Besides BHBA, acetoacetate is also absorbed efficiently from ruminal epithelium tissue. The relatively lower percentage mRNA abundance of $B D H 1$ may partly account for the quantitative release of acetoacetate into portal blood (Beck et al., 1984).

Although speculative, the fact that HMGCS2 was by far the most abundant gene examined is suggestive of an adaptive mechanism in the developing ruminal epithelium to ensure that enough HMG-CoA is available for subsequent production of BHBA via $B D H 1$; that is, HMGCS2 catalyzes the rate-limiting reaction of ruminal ketogenesis, as is the case in liver. If this hypothesis holds true, it may explain the relatively lower percentage mRNA abundance of $A C A T 1$; that is, flux of acetyl-CoA through ruminal ketogenesis is primarily at the level of HMGCS2 and not ACAT1. Under different nutritional and hormonal conditions, the level of HMGCS2 mRNA is strongly correlated with the rate of ketogenesis (Hegardt, 1999); thus, it is evident that changes in mRNA of this enzyme are important in its overall control over the mitochondrial ketogenesis.

Except for $H M G C L$, we observed no differences due to plane of nutrition for the expression of genes in the ketogenesis pathway. This appears consistent with data from dairy cows reported previously in which no effect on mRNA expression of ketogenic enzymes was found due to feeding a high-forage versus a high-concentrate diet (Penner et al., 2009). Harmon et al. (1991) reported no differences in the net production of acetoacetate and BHBA from acetate and butyrate by ruminal papillae slices harvested from beef cattle fed $90 \%$ concentrate or $90 \%$ forage diets; however, they detected increased oxidation of acetate and butyrate with the $90 \%$ concentrate diet. The present and previous data (Harmon et al., 1991; Lane et al., 2002) suggest that transcriptional adaptations of ketogenic enzymes in the developing ruminal epithelium are more a function of age than plane of nutrition. However, the differences in reticulorumen mass observed at wk 10 also seem to indicate that ENH might have provided additional substrate for metabolism; that is, a feed-forward effect on flux through metabolic pathways.

\section{Pyruvate and Propionate Metabolism}

Ruminal epithelium readily metabolizes pyruvate, which contributes carbon for the production of oxaloacetate, lactate, or ketone bodies (Pennington and Sutherland, 1955). The greater starter consumption in calves fed the control diet at wk 5 (Table 1; Figure 1) might have led to greater $P C C A$ expression by wk 10 , a response that carried through wk 10 when the nutrient profile of starter was different in calves fed ENH. The increase in $L D H A$ expression between wk 5 and 10 in calves fed ENH was also suggestive of composition of starter having an effect on fermentation, which, in turn, affected mRNA expression in ruminal epithelial cells. Greater lactate and pyruvate production, along with an increase in propionate production, were reported when ruminal epithelial cells were incubated with increasing amounts of propionate (Baldwin and Jesse, 1996). In another study, propionate metabolism in vitro resulted in greater pyruvate and lactate production in ruminal epithelium from steers fed a $90 \%$ concentrate diet than in tissue from steers fed a $90 \%$ forage diet for $140 \mathrm{~d}$ (Harmon et al., 1991). Although we did not measure 
ruminal VFA profiles, it is likely that greater starter intake through wk 5 in controls and greater fermentation of starter over time in ENH may have played a role in the observed expression patterns of $P C, P C C A$, and $L D H A$. However, the relatively lower percentage mRNA abundance of PCCA $(0.24 \%)$ and $L D H A$ (1.34\%) compared with ketogenic genes suggested that propionate metabolism in these young calves was minor and in accordance with the low rates of propionate metabolism by ruminal epithelium published previously (Remond et al., 1995).

Despite greater daily starter intake (CP 20.5\%) in calves fed enhanced MR (28\% CP plus $20 \%$ fat) compared with calves fed conventional MR (20\% CP plus $20 \%$ fat), Bridges (2009) noted higher propionate concentration at wk 4 in controls, which might explain our observation of higher $P C C A$ expression when feeding the control diet. Although we found no change in expression of $I D H 1$, considering its involvement in generating $\mathrm{NADPH}$ in the cytosol during ruminant lipogenesis, it was noteworthy that $I D H 1$ relative percentage mRNA abundance $(\sim 2.5 \%$ of total mRNA) was higher compared with other tricarboxylic acid (TCA) cycle (OGDH, PDHA1, GOT2, GLUD1, PC) or cytosolic enzymes $(L D H A, L D H B)$ that would be expected to play a more important role during ruminal cell metabolism. It is possible that IDH1 contributes to TCA cycle flux in these cells through continued production of $\alpha$-ketoglutarate, which upon entry into mitochondria could be metabolized by $O G D H$ (Bauman et al., 1970). The greater relative percentage mRNA abundance of MDH2 ( $2 \%$ of total mRNA) and the fact that $P C$ relative mRNA abundance was quite low $(<0.01 \%)$ seems to indicate that metabolism of pyruvate in the TCA cycle of developing ruminal epithelium is minor and does not contribute quantitatively to production of oxaloacetate or acetyl-CoA. Although not measured in our study, the fact that abundance of $M D H 2$ was higher than that of GOT2 was indicative of greater influx of cytosolic malate into mitochondria.

\section{LCFA Oxidation}

Long-chain fatty acids are essential metabolic fuels. Oxidation of LCFA such as palmitate may provide acetyl-CoA for ketogenesis in ruminal epithelium cells (Jesse et al., 1992). Besides their role in metabolism, LCFA also are essential for cellular membranes of proliferating cells. Thus, the intracellular concentration of LCFA is highly regulated. In nonruminants, it is well established that LCFA metabolism is regulated by members of the nuclear receptor family of ligandactivated transcription factors, peroxisome proliferator- activated receptors (PPAR; Burdick et al., 2006). The $P P A R$ heterodimerize with the retinoic $\mathrm{X}$ receptor (RXR) after activation and bind specific sequences in the promoter region called peroxisomal proliferator response elements. Target genes of PPARA are involved in mitochondrial and peroxisomal $\beta$-oxidation of LCFA and in the production of "hepatokines" including ANGPTL4 and FGF21 (e.g., Loor et al., 2007; Vilà-Brau et al., 2011). A role for PPARA in catabolism of FA and epithelial cell proliferation and keratinization has been reported previously (Burdick et al., 2006). In some cell systems, PPARD partly inhibits the action of PPARA through binding to peroxisomal proliferator response elements after interacting with co-repressors such as SMRT (Burdick et al., 2006).

The enzymes CPT1A and ACADVL catalyze the entry of LCFA into mitochondria and the first step of mitochondrial oxidation of LCFA (Zammit, 1984). Greater expression of CPT1A at wk 5 than wk 10 might have been partly related to LCFA intake from MR; that is, developing ruminal tissue has the ability to utilize LCFA as energy source, as shown by Jesse et al. (1992). This suggestion agrees with the percentage relative abundance $(\sim 1.3 \%$ of total mRNA) of $C P T 1 A$ and $A C A D V L$. Higher overall expression of PPARA at wk 5 but higher PPARD at wk 10 was suggestive of different regulatory mechanisms for the PPAR isoforms, perhaps driven by a combination of substrate availability (e.g., dietary LCFA), the need to promote cell differentiation, or both. For example, higher PPARA at wk 5 was suggestive of more reliance on LCFA in the milk-fed period (e.g., higher blood NEFA) likely driven by the greater intake of LCFA from MR.

The percentage relative abundance of both PPAR transcripts studied also was quite unexpected; that is, the PPARD isoform was substantially more abundant than PPARA, which potentially underscores different functions of these isoforms in ruminal cells. This type of isoform distribution also contrasts that of liver (both ruminant and nonruminant), where PPARA is substantially more abundant than PPARD (Khan et al., 2011). Interestingly, feeding ENH resulted in lower PPARA at wk 5 , which corresponded with markedly greater blood NEFA and glucose. Ruminal tissue from calves fed ENH may have relied more heavily on glucose than NEFA as oxidative fuel. The increase in PPARD at wk 10 may have been an adaptation to counteract the decrease in LCFA intake from MR (i.e., lower substrate availability for oxidation). However, if we assume that PPARA inhibition by $P P A R D$ also operates in ruminal cells, it would indicate a more important role for PPARD in promoting LCFA use for cellular membranes during differentiation. The decrease in $C P T 1 A$ and $A C A D V L$ 
and the hepatokine ANGPTL4 by wk 10 (PPAR targets in ruminants and nonruminants) seems to support this suggestion.

Besides its role in LCFA oxidation, PPARA also is involved in transcriptional regulation of ketogenic genes, especially HMGCS2, but also the metabolic growth factor FGF21 (Rodriguez et al., 1994; Vilà-Brau et al., 2011). In nonruminants, PPARA induces HMGCS2, $A C A D V L, C P T 1 A$, and FGF21 expression by binding directly to DNA response elements in their promoter (Rodriguez et al., 1994; Vilà-Brau et al., 2011). Additionally, expression of $H M G C S 2$ was necessary for induction of expression of FGF21 in cultured HepG2 cells (Vilà-Brau et al., 2011), which underscores the link between LCFA, fatty acid oxidation, ketogenesis, and activation of FGF21. Recent data have provided evidence that activation of bovine PPARA in vitro leads to upregulation of $H M G C S 2, A C A D V L$, and CPT1A as well as ANGPTL4 (Bionaz et al., 2012). However, a decrease in expression of FGF21 with time in this study does not seem to support a direct relationship with HMGCS2 as in nonruminants; however, such a decrease over time was similar to the decrease in blood NEFA and PPARA expression, suggesting a link between ruminal fatty acid oxidation and FGF21 as has been observed previously in nonruminant liver.

Despite the above data supporting LCFA oxidation by ruminal cells, it was shown previously that in the presence of butyrate at physiological concentrations (10 $\mathrm{m} M$ ), palmitate oxidation in isolated ruminal epithelial cells of sheep was reduced to one-half that of butyrate (Jesse et al., 1992). Furthermore, palmitate oxidation was also inhibited in the presence of $\mathrm{NH}_{3}(15 \mathrm{mM}$; Jesse et al., 1992). The lack of treatment effect on CPT1A and the weak effect on $A C A D V L$, coupled with the low relative percentage mRNA abundance of both enzymes argues against LCFA oxidation being quantitatively important in ruminal cells. In fact, it is evident from our results with $A C A D S B$ and $A C A D S$ that ruminal epithelium is likely more reliant on oxidation of short- and branched-chain FA to derive energy because these 2 genes accounted for 2 to $3 \%$ of total mRNA measured. The lower expression of $A C A D S B$, which is specific for short- and branched-chain FA (Rozen et al., 1994), in calves fed ENH might have been related to the lower starter intake during the first $5 \mathrm{wk}$, whereas starter composition seems to have been a determinant factor for differences in $A C A D S B$ through wk 10. The control starter had greater percentages of wheat middlings (46 vs. $5 \%$ ) and distillers grains (10 vs. $5 \%$ ), but lower content of soybean meal (34 vs. $77 \%$ ) compared with ENH (Stamey, 2008). With the exception of fiber, the feeding value of wheat middlings is similar to that of cereal grains. Previous and current data indicate that the energy requirement of ruminal epithelial cells is tightly regulated by availability of fuels, metabolism, and likely transcriptional regulation of enzymes.

\section{Urea Transport}

Metabolism of urea in the rumen is of extreme importance in terms of supplying $\mathrm{N}$ for synthesis of microbial protein (Aschenbach et al., 2011). Immunolocalization studies by Stewart et al. (2005) showed the presence of SLC14A1, formerly known as UT-B protein, within the cell membrane of the stratum basale, spinosum, and granulosum of the ruminal epithelium, suggesting a role in transport of urea from the blood into the rumen (Stewart et al., 2005). The higher expression of SLC14A1 at wk 10 corresponded with the increase in BUN concentration. Although diet effects on mRNA and protein expression of SLC14A1 have been documented previously (Simmons et al., 2009), we did not find any differences due to plane of nutrition. Simmons et al. (2009) noted greater mRNA and protein expression of SLC14A1 in ruminal epithelium of steers fed a concentrate-based diet or silage-based diet with similar CP content $(\sim 13.4 \%)$ for $37 \mathrm{~d}$. As stated previously, ruminal VFA concentration was not measured in our study but it has been argued (Simmons et al., 2009) that higher production of butyrate due to high-grain diets might also influence expression of SLC14A1. Despite the greater BUN concentration in calves fed ENH at wk 5 and 10, differences in SLC14A1 between treatments were not statistically significant (although they were numerically different at wk 5) due to large variation. As argued above, differences in starter intake during the milk-fed period may have been associated with those numerical differences.

The marked increase in $S L C 14 A 1$ expression at wk 10 regardless of treatment may be indicative of a scavenging mechanism to secure more $\mathrm{N}$ to enhance microbial growth and metabolism by facilitating direct passage of liver-derived urea from the blood to the lumen of the rumen (Simmons et al., 2009; Aschenbach et al., 2011). The mechanistic relationship between urea transporter expression and microbial $\mathrm{N}$ requirements will have to be studied in more detail in the future. One practical observation that could be proposed from our gene expression and blood measurements of $\mathrm{N}$ metabolism is that dietary treatments between wk 5 and wk 10 were not sufficient to meet microbial needs; that is, more urea- $\mathrm{N}$ had to be recycled back into the rumen.

\section{Insulin Signaling Pathway}

The intake of protein- and energy-rich diets promotes the growth of ruminal tissues through increases in 
epithelial cell proliferation (Shen et al., 2004). Insulin and IGF-1 are known to regulate ruminal epithelial cell proliferation (Baldwin, 1999) in cooperation with their receptors INSR and IGF1R. Insulin can mediate its effect on ruminal cell proliferation partly through its greater release into circulation in response to high VFA production (Dimitriadis et al., 2011). In Caco-2 and DLD-1 intestinal cell lines, upon binding to their receptors, these growth factors initiate a signal transduction cascade that results in expression of extracellularrelated protein kinases involved in proliferation; for example, the serine/threonine protein kinase, AKT, and mTOR. No previous reports have been published on the mRNA expression of these kinases in bovine ruminal epithelium.

The relatively higher percentage of $A K T 1 \mathrm{mRNA}$ (1.69\%) compared with AKT2 or AKT3 and its numerically higher gene expression with ENH at wk 10 was suggestive of a potentially important role in the observed response of reticulorumen mass. By far, AKT1 is the most abundant AKT isoform in rodent muscle and is activated in response to IGF-1 (Sandri, 2008). The lower AKT3 expression with ENH at wk 10 seemed opposite to its previously reported role in coordinating the increase in organ weight via promoting cell proliferation in mice (Dummler et al., 2006). Similar to AKT1, mTOR (a downstream effector of insulin signaling) participates in the control of cell growth in response to growth factors and nutrients (Kim et al., 2003). A decrease in expression of mTOR over time corresponded well with the other mediators of insulin signaling (e.g., AKT1, IGF1, and INSR) and may indicate their concerted action in regulating aspects of ruminal cell development and growth.

In our study, calves fed ENH had greater reticulorumen mass at $10 \mathrm{wk}$, confirming earlier evidence of dietary regulation (Stobo et al., 1966). In the absence of differences in reticulorumen mass, the greater mean blood insulin, glucose, live weights, and carcass weights during the milk-fed period for calves fed ENH compared with controls was suggestive of a lack of response of ruminal tissue to enhanced nutrient availability. At a more mechanistic level, the greater expression of INSR with $\mathrm{ENH}$ at wk 5 was associated with greater blood insulin, but the fact that FOXO1 expression was also greater suggested the existence of a feedback mechanism to dampen or control insulin signaling. Sakata et al. (1980) showed a significant increase in mitotic activity of ruminal epithelium cells isolated from sheep infused for $6 \mathrm{~h}$ with insulin plus glucose into the jugular vein compared with sheep infused with glucose alone or saline. Those data seem to agree with greater blood insulin and reticulorumen mass at wk 10 due to feeding ENH. Further investigation on how insulin, IGF-1, and their receptors interact to coordinate ruminal epithelial cell adaptations under changing dietary conditions is warranted.

\section{CONCLUSIONS}

Diet-dependent functional and metabolic changes in ruminal epithelium are of obvious practical importance. Despite the greater serum insulin, our results indicated that upregulation of genes related to insulin and IGF-1 signaling due to enhanced milk replacer was not clearly associated with differences in reticulorumen mass during the preweaning phase. Thus, although the preweaned tissue may be responsive to those hormones, additional mechanisms are required to elicit a full pro-developmental response at an early age. Because mRNA for the rate-limiting ketogenic enzyme HMGCS2 was markedly downregulated due to enhanced milk replacer, it could be possible that hormones (e.g., insulin induced by the high blood glucose) or lack of ruminally derived butyrate (i.e., lower starter intake) were limiting factors for reticuloruminal development. However, it was evident that provision of high-CP starter postweaning not only enhanced expression of HMGCS2 and enzymes promoting pyruvate metabolism and TCA cycle flux but also led to greater serum insulin and reticuloruminal tissue mass. Thus, it is possible that insulin also contributes to promoting reticuloruminal mass accretion after weaning. Despite a lack of ruminal VFA profiles, the gene expression patterns observed across several biological processes, along with the intake and blood data, provided an indication of causal associations between plane of nutrition and molecular mechanisms associated with ruminal tissue development. Overall, results from gene expression and tissue mass underscore the importance of high-quality starter composition on ruminal development. The relevance of such responses to future productivity (e.g., milk production) will have to be evaluated in dairy heifers.

\section{REFERENCES}

Aschenbach, J. R., G. B. Penner, F. Stumpff, and G. Gabel. 2011. Ruminant Nutrition Symposium: Role of fermentation acid absorption in the regulation of ruminal pH. J. Anim. Sci. 89:1092-1107.

Baldwin, R. L. VI. 1999. The proliferative actions of insulin, insulinlike growth factor-I, epidermal growth factor, butyrate and propionate on ruminal epithelial cells in vitro. Small Rumin. Res. 32:261-268.

Baldwin, R. L. VI, and B. W. Jesse. 1992. Developmental changes in glucose and butyrate metabolism by isolated sheep ruminal cells. J. Nutr. 122:1149-1153.

Baldwin, R. L., and B. W. Jesse. 1996. Propionate modulation of ruminal ketogenesis. J. Anim. Sci. 74:1694-1700.

Bartlett, K. S., F. K. McKeith, M. J. VandeHaar, G. E. Dahl, and J. K. Drackley. 2006. Growth and body composition of dairy calves fed milk replacers containing different amounts of protein at two feeding rates. J. Anim. Sci. 84:1454-1467. 
Bauman, D. E., R. E. Brown, and C. L. Davis. 1970. Pathways of fatty acid synthesis and reducing equivalent generation in mammary gland of rat, sow, and cow. Arch. Biochem. Biophys. 140:237-244.

Beck, U., B. Emmanuel, and D. Giesecke. 1984. The ketogenic effect of glucose in rumen epithelium of ovine (Ovis aries) and bovine (Bos taurus) origin. Comp. Biochem. Physiol. B 77:517-521.

Bilk, S., K. Huhn, K. U. Honscha, H. Pfannkuche, and G. Gabel. 2005. Bicarbonate exporting transporters in the ovine ruminal epithelium. J. Comp. Physiol. B 175:365-374.

Bionaz, M., B. J. Thering, and J. J. Loor. 2012. Fine metabolic regulation in ruminants via nutrient-gene interactions: Saturated long-chain fatty acids increase expression of genes involved in lipid metabolism and immune response partly through PPAR- $\alpha$ activation. Br. J. Nutr. 107:179-191. http://dx.doi.org/10.1017/ S0007114511002777.

Blome, R. M., J. K. Drackley, F. K. McKeith, M. F. Hutjens, and G. C. McCoy. 2003. Growth, nutrient utilization, and body composition of dairy calves fed milk replacers containing different amounts of protein. J. Anim. Sci. 81:1641-1655.

Bödeker, D., G. Oppelland, and H. Holler. 1992. Involvement of carbonic anhydrase in ammonia flux across rumen mucosa in vitro. Exp. Physiol. 77:517-519.

Bridges, A. J. 2009. Effect of milk replacer composition on growth and rumen development of neonatal Holstein calves. MS Thesis. Louisiana State University, Baton Rouge.

Brunengraber, H., M. Boutry, and J. M. Lowenstein. 1978. Fatty acid, 3- $\beta$-hydroxysterol and ketone synthesis in the perfused rat liver. Effects of (-)-hydroxycitrate and oleate. Eur. J. Biochem. 82:373-384.

Burdick, A. D., D. J. Kim, M. A. Peraza, F. J. Gonzalez, and J. M. Peters. 2006. The role of peroxisome proliferator-activated receptor-beta/delta in epithelial cell growth and differentiation. Cell. Signal. 18:9-20.

Burg, J. S., and P. J. Espenshade. 2011. Regulation of HMG-CoA reductase in mammals and yeast. Prog. Lipid Res. 50:403-410.

Carter, M. J. 1971. The carbonic anhydrase in the rumen epithelial tissue of the ox. Biochim. Biophys. Acta 235:222-236.

Connor, E., R. Li, R. L. Baldwin VI, and C. Li. 2010. Gene expression in the digestive tissues of ruminants and their relationships with feeding and digestive processes. Animal 4:993-1007.

Diaz, M. C., M. E. Van Amburgh, J. M. Smith, J. M. Kelsey, and E. L. Hutten. 2001. Composition of growth of Holstein calves fed milk replacer from birth to 105-kilogram body weight. J. Dairy Sci. 84:830-842.

Dimitriadis, G., P. Mitron, V. Lambadiari, E. Maratou, and S. A. Raptis. 2011. Insulin effects in muscle and adipose tissue. Diabetes Res. Clin. Pract. 93(Suppl. 1):S52-S59.

Dummler, B., O. Tschopp, D. Hynx, Z. Z. Yang, S. Dirnhofer, and B. A. Hemmings. 2006. Life with a single isoform of Akt: Mice lacking Akt2 and Akt3 are viable but display impaired glucose homeostasis and growth deficiencies. Mol. Cell. Biol. 26:8042-8051.

Graham, C., I. Gatherar, I. Haslam, M. Glanville, and N. L. Simmons. 2007. Expression and localization of monocarboxylate transporters and sodium/proton exchangers in bovine rumen epithelium. Am. J. Physiol. Regul. Integr. Comp. Physiol. 292:R997-R1007.

Harmon, D. L., K. L. Gross, C. R. Krehbiel, K. K. Kreikemeier, M. L. Bauer, and R. A. Britton. 1991. Influence of dietary forage and energy intake on metabolism and acyl-CoA synthetase activity in bovine ruminal epithelial tissue. J. Anim. Sci. 69:4117-4127.

Hegardt, F. G. 1999. Mitochondrial 3-hydroxy-3-methylglutaryl-CoA synthase: A control enzyme in ketogenesis. Biochem. J. 338:569 582 .

Ikuma, M., J. Geibel, H. J. Binder, and V. M. Rajendran. 2003. Characterization of $\mathrm{Cl}-\mathrm{HCO} 3$ exchange in basolateral membrane of rat distal colon. Am. J. Physiol. Cell Physiol. 285:C912-C921.

Jesse, B. W., R. K. Solomon, and R. L. Baldwin VI.. 1992. Palmitate metabolism by isolated sheep rumen epithelial cells. J. Anim. Sci. 70:2235-2242.

Khan, J., D. E. Graugnard, D. H. Keisler, B. J. Bradford, L. K. Mamedova, J. K. Drackley, and J. J. Loor. 2011. Hepatokine, growth hormone, and PPAR $\alpha$-regulated gene network expression in liver of peripartal cows fed two levels of dietary energy prepartum. J. Dairy Sci. 94(E-Suppl. 1):732. (Abstr.)

Kim, D. H., D. D. Sarbassov, S. M. Ali, R. R. Latek, K. V. P. Guntur, H. Erdjument-Bromage, P. Tempst, and D. M. Sabatini. 2003. $\mathrm{G} \beta \mathrm{L}$, a positive regulator of the rapamycin-sensitive pathway required for the nutrient-sensitive interaction between Raptor and mTOR. Mol. Cell 11:895-904.

Koho, N., V. Maijala, H. Norberg, M. Nieminen, and A. R. Poso. 2005. Expression of MCT1, MCT2 and MCT4 in the rumen, small intestine and liver of reindeer (Rangifer tarandus tarandus L.). Comp. Biochem. Physiol. A Mol. Integr. Physiol. 141:29-34.

Lane, M. A., R. L. Baldwin VI, and B. W. Jesse. 2000. Sheep rumen metabolic development in response to age and dietary treatments. J. Anim. Sci. 78:1990-1996.

Lane, M. A., R. L. Baldwin VI, and B. W. Jesse. 2002. Developmental changes in ketogenic enzyme gene expression during sheep rumen development. J. Anim. Sci. 80:1538-1544.

Leighton, B., A. R. Nicholas, and C. I. Pogson. 1983. The pathway of ketogenesis in rumen epithelium of the sheep. Biochem. J. 216:769-772.

Loor, J. J., H. M. Dann, R. E. Everts, R. Oliveira, C. A. Green, N. A Guretzky, S. L. Rodriguez-Zas, H. A. Lewin, and J. K. Drackley. 2005. Temporal gene expression profiling of liver from periparturient dairy cows reveals complex adaptive mechanisms in hepatic function. Physiol. Genomics 23:217-226.

Loor, J. J., R. E. Everts, M. Bionaz, H. M. Dann, D. E. Morin, R. Oliveira, S. L. Rodriguez-Zas, J. K. Drackley, and H. A. Lewin. 2007. Nutrition-induced ketosis alters metabolic and signaling gene networks in liver of periparturient dairy cows. Physiol. Genomics 32:105-116.

Müller, F., K. Huber, H. Pfannkuche, J. R. Aschenbach, G. Breves, and G. Gabel. 2002. Transport of ketone bodies and lactate in the sheep ruminal epithelium by monocarboxylate transporter 1. Am. J. Physiol. Gastrointest. Liver Physiol. 283:G1139-G1146.

Penner, G. B., M. Taniguchi, L. L. Guan, K. A. Beauchemin, and M. Oba. 2009. Effect of dietary forage to concentrate ratio on volatile fatty acid absorption and the expression of genes related to volatile fatty acid absorption and metabolism in ruminal tissue. J. Dairy Sci. 92:2767-2781.

Pennington, R. J., and T. M. Sutherland. 1955. The production of succinate from propionate by carbon dioxide fixation in sheep rumen epithelial tissue. Biochem. J. 60:xxxvii.

Rémond, D., I. Ortigues, and J. P. Jouany. 1995. Energy substrates for the rumen epithelium. Proc. Nutr. Soc. 54:95-105.

Rodríguez, J. C., G. Gilgomez, F. G. Hegardt, and D. Haron. 1994 Peroxisome proliferator-activated receptor mediates induction of the mitochondrial 3-hydroxy-3 methylglutaryl-CoA synthase gene by fatty-acids. J. Biol. Chem. 269:18767-18772.

Rozen, R., J. Vockley, L. Zhou, R. Milos, J. Willard, K. Fu, C. Vicanek, L. Low-Nang, E. Torban, and B. Fournier. 1994. Isolation and expression of a cDNA encoding the precursor for a novel member (ACADSB) of the acyl-CoA dehydrogenase gene family. Genomics 24:280-287.

Sakata, T. K. Hikosaka, Y. Shiomura, and H. Tamate. 1980. Stimulatory effect of insulin on ruminal epithelium cell mitosis in adult sheep. Br. J. Nutr. 44:325-331.

Sandri, M. 2008. Signaling in muscle atrophy and hypertrophy. Physiology (Bethesda) 23:160-170.

Sepponen, K., N. Koho, E. Puolanne, M. Ruusunen, and A. R. Poso. 2003. Distribution of monocarboxylate transporter isoforms MCT1, MCT2 and MCT4 in porcine muscles. Acta Physiol. Scand. 177:79-86.

Shen, Z., H. M. Seyfert, B. Lohrke, F. Schneider, R. Zitnan, A. Chudy, S. Kuhla, H. M. Hammon, J. W. Blum, H. Martens, H. Hagemeister, and J. Voigt. 2004. An energy-rich diet causes rumen papillae proliferation associated with more IGF type 1 receptors and increased plasma IGF-1 concentrations in young goats. J. Nutr. 134:11-17.

Simmons, N. L., A. S. Chaudhry, C. Graham, E. S. Scriven, A. Thistlethwaite, C. P. Smith, and G. S. Stewart. 2009. Dietary regulation 
of ruminal bovine UT-B urea transporter expression and localization. J. Anim. Sci. 87:3288-3299.

Stamey, J. A. 2008. Influence of starter protein content and plane of nutrition on growth and body composition of dairy calves. MS Thesis. University of Illinois, Urbana.

Stewart, G. S., C. Graham, S. Cattell, T. P. Smith, N. L. Simmons, and C. P. Smith. 2005. UT-B is expressed in bovine rumen: Potential role in ruminal urea transport. Am. J. Physiol. Regul. Integr. Comp. Physiol. 289:R605-R612.

Stobo, I. J., J. H. Roy, and H. J. Gaston. 1966. Rumen development in the calf. 2. The effect of diets containing different proportions of concentrates to hay on digestive efficiency. Br. J. Nutr. 20:189215 .

Van Soest, P. J. 1994. Function of the ruminant forestomach. Pages 230-252 in Nutritional Ecology of the Ruminant. Vol. 2. Cornell University Press, Ithaca, NY.
Vilà-Brau, A., A. L. De Sousa-Coelho, C. Mayordomo, D. Haro, and P. F. Marrero. 2011. Human HMGCS2 regulates mitochondrial fatty acid oxidation and FGF21 expression in HepG2 cell line. J. Biol. Chem. 286:20423-20430.

Wang, L. Q., R. L. Baldwin VI, and B. W. Jesse. 1996. Isolation and characterization of a cDNA clone encoding ovine type I carbonic anhydrase. J. Anim. Sci. 74:345-353.

Weigand, E., J. W. Young, and A. D. McGilliard. 1972. Extent of propionate metabolism during absorption from the bovine ruminoreticulum. Biochem. J. 126:201-209.

Zammit, V. A. 1984. Mechanisms of regulation of the partition of fatty acids between oxidation and esterification in the liver. Prog. Lipid Res. 23:39-67. 